\title{
キジ目鳥類における種間雑種の存在
}

\author{
西堀正英 1 . 安江 博 2 \\ ${ }^{1}$ 広島大学大学院 生物圈科学研究科 応用動物科学講座、2 農業生物資源研究所 動物ゲノムグループ
}

\section{Evidence for hybridization of species in the order Galliformes based on molecular and population genetics}

\author{
Masahide NISHIBORI ${ }^{1}$ and Hiroshi YASUE ${ }^{2}$ \\ ${ }^{1}$ Department of Bioresource Science and Technology, Graduate School of Biosphere Science, Hiroshima University \\ 2 Genome Research Department, National Institute of Agrobiological Sciences
}

\section{1. はじめに}

ラバ (騾馬：Mule) は、雄ロバと雌ウマとの一代種 間雑種で生殖能力を持たないが、役畜に適し利用価值 が高いとされている。一方、雄ウマと雌ロバとの種間 雑種はケッテイ (駅騠：Hinny）とよばれ、役能力がや や劣るためにあまり利用されていない。家畜の場合は 良い性質を持つものを得るために人為的に雑種を作り 出されてきた。一般に雑種は両親のいずれかの種の形 質より優れていることが多く、これを雑種強勢といい、 ラバやトウホアンアー (土蕃鴨) (菜鴨 (ツアイアー)の 雄とバリケンの雌を交雑) がこの例である。また、動 物園では、ライガー、レオポン、タイゴンなどの人気 の高いネコ科の動物について人為的に種間雑種が作ら れた。これらのほとんどは、一代雑種であり、生殖能 力に乏しく雑種同士の交配はできないことが多いと されている。キジ目鳥類では、キンケイ雄とキジ雌 を交雑し、テンケイと称し、食肉用として飼育され ている。

形態形質や妊性などの繁殖性を調査する目的での人 為交雑による雑種の研究はあるが、自然状態における 雑種の現状を分子遺伝学的に明らかにした報告はほと んどない。著者ら（Nishibori ら 2005）は、ニワトリ（鶏） とヤケイ (野鶏：セキショクヤケイ、ハイイロヤケイ、 セイロンヤケイ、アオエリヤケイ)との類縁関係を分 子遺伝学的に解析する中で、ニワトリとヤケイとの間 で種間雑種が存在していることを発見した。また、ア カアシイワシャコとイワシャコとの間に雑種が存在 することを分子遺伝学的に明らかにした報告もある (Baratti ら 2004)。本稿では、キジ目鳥類の自然下で の雑種とその研究の現状を紹介し、キジ目鳥類を分 類学的立場から、および遺伝資源保護の見地から考
察する。

\section{2. 種}

一般に動物における「種」とは、マイヤーの生物学 的種の概念により、「種は実際あるいは潜在的に交配 可能な自然個体群の集まりをいい、これらの個体群 は他の種の個体群とは繁殖の上で隔離されている」 (Mayr 1942) と定義されている。つまり、「種」として 分類された分類群を構成するメンバーは互いに交配可 能で交配によって生まれた個体は妊性を有する。メン バー間で遺伝子のやりとりが行われ、それらは全体と して遺伝子の集合体であるゲノム群 (遺伝子プール)を 共有している。一方、「生物学的別種」のメンバーと は生殖的に隔離されている。したがって、仮に、「生 物学的別種」のメンバーと偶発的に交雑が起こり、そ れにより子供が誕生しても、その子供は妊性を持たず、 子孫を形成できない。しかしながら、現在の動物の分 類は、こうした生物学的種の概念に厳密にしたがった 分類になっていないものも多く存在すると考えられる。

\section{3. 雑種}

雑種とは、受精卵の核自体が2つの動物種由来の染 色体を持つもので、この生物個体のすべての細胞の核 内に 2 種の遺伝子が存在する個体である。この個体の すべての細胞は同じ遺伝子セットを持っている。つま

連絡先：西堀正英、広島大学大学院 生物圈科学研究科 応用 動物科学講座 T739-8528 広島県東広島市鏡山 1-4-4 (e-mail: nishibo@hiroshima-u.ac.jp) 
り別種間で交雑し、その誕生した子孫を雑種という。 雑種は一般に、前述のようなラバなど一代雑種で生殖 能力を持たないが、雑種強勢 (雑種強勢とは、雑種で ある子の能力が、兩親よりもすぐれている現象のこと をいい、特に強健性や抗病性、生産性に効果が現れる) により実用的に利用価值が高いとされているものが多 い。ロバの染色体は 62 本 (配偶子は 31 本)、ウマの染 色体は 64 本 (配偶子は 32 本) である。種間雑種のラバ の染色体は 63 本 $(31$ 本 +32 本) となり、このため対に ならない染色体ができ、減数分裂が不規則になる。こ れがラバに妊性がない理由である。

しかしながら、上述したように、現在の動物の分類 では「生物学的種の概念」だけをべースにしたもので はないため、自然界で現在の「種」の間で交雑が起こ る(起こっている) 可能性もある。自然界での「種」間 交雑の可能性については、それらの種間での生殖隔離 の有無、加えてそれら2つの生物種群が時間と空間を 共有して生息している (同所的) かどうかについて検討 する必要がある。

\section{4. キジ目}

キジ目は、生態・地理学的および生理・形態学的特 徵からッカックリ科 (Megapodidae)、ホウカンチョウ 科 (Cracidae)、キジ科 (Phasianidae)、ホロホロチョウ 科 (Numididae)、ハウズラ科 (Odontophoridae) の 5 科に 分類されている。さらにこれら 5 科は 75 属 283 種に分 類されている (Sibleyと Ahlquist 1990)（表1）。キジ科 は、 45 属 177 種とキジ目の中で最も多くの種が分類さ れている。また、キジ科では、その形態形質からシャ

表 1. キジ目の分類（genus：属／species：種）

\begin{tabular}{l}
\hline family Megapodidae $(6 / 19) \quad$ : ツカツクリ科 \\
megapode, scrubfowl, brush-turkey \\
family Cracidae $(11 / 50) \quad$ : ホウカンチョウ科 \\
guan, chachalaca, curassow \\
family Phasianidae $(45 / 177) \quad$ : キジ科 \\
junglefowl, pheasant, grouse, peafowl, \\
old world quail (rock partridge, Japanese quail), etc. \\
family Numididae (4/6) $\quad$ : ホロホロチョウ科 \\
guineafowl \\
family Odontophoridae (9/31) : ハウズラ科 \\
new world quail (California quail) etc.
\end{tabular}

(Sibley and Monroe, 1990)
コ族 (tribe Perdicini) とキジ族 (tribe Phasianini) とに分 類されている (Johnsgard 1999)。シャコ族 (Perdicini; old world quail, partridge, and francolin) は、一般に小型 でニホンウズラ (Japanese quail: Coturnix japonica) やコ ジュケイ (Chinese Bamboo Partridge: Bambusicola thoracica) などが含まれる。一方、キジ族 (Phasianini; pheasants, junglefowl, and peafowl) は、一般に大型であ り、ニワトリ (Gallus gallus var. domesticus) やニホンキ ジ (Green pheasant: Phasianus versicolor)などが含まれ る(Johnsgard 1999)。

著者らは、現在キジ目のより詳細かつ信頼性の高い 系統を分子系統学的に解析するために、ミトコンドリ アゲノム (mtDNA) の全塩基配列を決定し、分子系統 樹を作成して系統解析を行っている。すでにキジ目 33 種について全 mtDNA の塩基配列を解析し、DNA デー タバンク (DDBJ/EMBL/GenBank) に登録した。キジ目 鳥類の mtDNAにおいて、著者らが塩基配列を決定し た種および他のグループによって報告されている種の 配列デー夕を用いて、キジ目の分子系統学的解析を行 った（図 1)。この中で、ミトコンドリアの塩基配列よ り第 3 コドンの塩基配列を抽出し、分子系統樹を作成 し、系統解析を行った結果を図 1 に示した。系統解析 にはコジュケイ (Chinese bamboo partridge: Bambusicola thoracica)、ヒメウズラ (Blue-breasted quail: Coturnix chinensis)、ニホンウズラ (Japanese quail: Coturnix japonica)、ニワトリ (Chicken: Gallus gallus var. domesticus)、アオエリヤケイ (Green junglefowl: Gallus varius)、ホロホロチョウ (Helmeted guineafowl: Numida meleagris)、インドクジャク (Indian peafowl: Pavo cristatus)、コウライキジ (Ring-neck pheasant: Phasianus colchicus)、ホソオライチョウ (Sharp-tailed groose: Tympanuchus phasianellus)、および外群にはアメリカ ホシハジロ (Redhead: Aythya americana)を用いた。こ の中で、ホソオライチョウはライチョウ科に、ホロホ ロチョウはホロホロチョウ科に、ニワトリ、アオエリ ヤケイ、コウライキジおよびインドクジャクはキジ科 キジ族に、ニホンウズラ、ヒメウズラ、コジュケイお よびヨーロッパヤマウズラはキジ科シャコ族に分類さ れている。(((((((ホソオライチョウ，ヨーロッパヤマ ウズラ), コウライキジ), (ヒメウズラ, ニホンウズ ラ)), インドクジャク), ((アオエリヤケイ，ニワトリ), コジュケイ)), ホロホロチョウ), アメリカホシハジ 口)となり（図 1)、これらの系統樹からニワトリ・アオ エリヤケイとコジュケイが単系統となり、またコウラ イキジとヨーロッパヤマウズラおよびヒメウズラ・ニ 


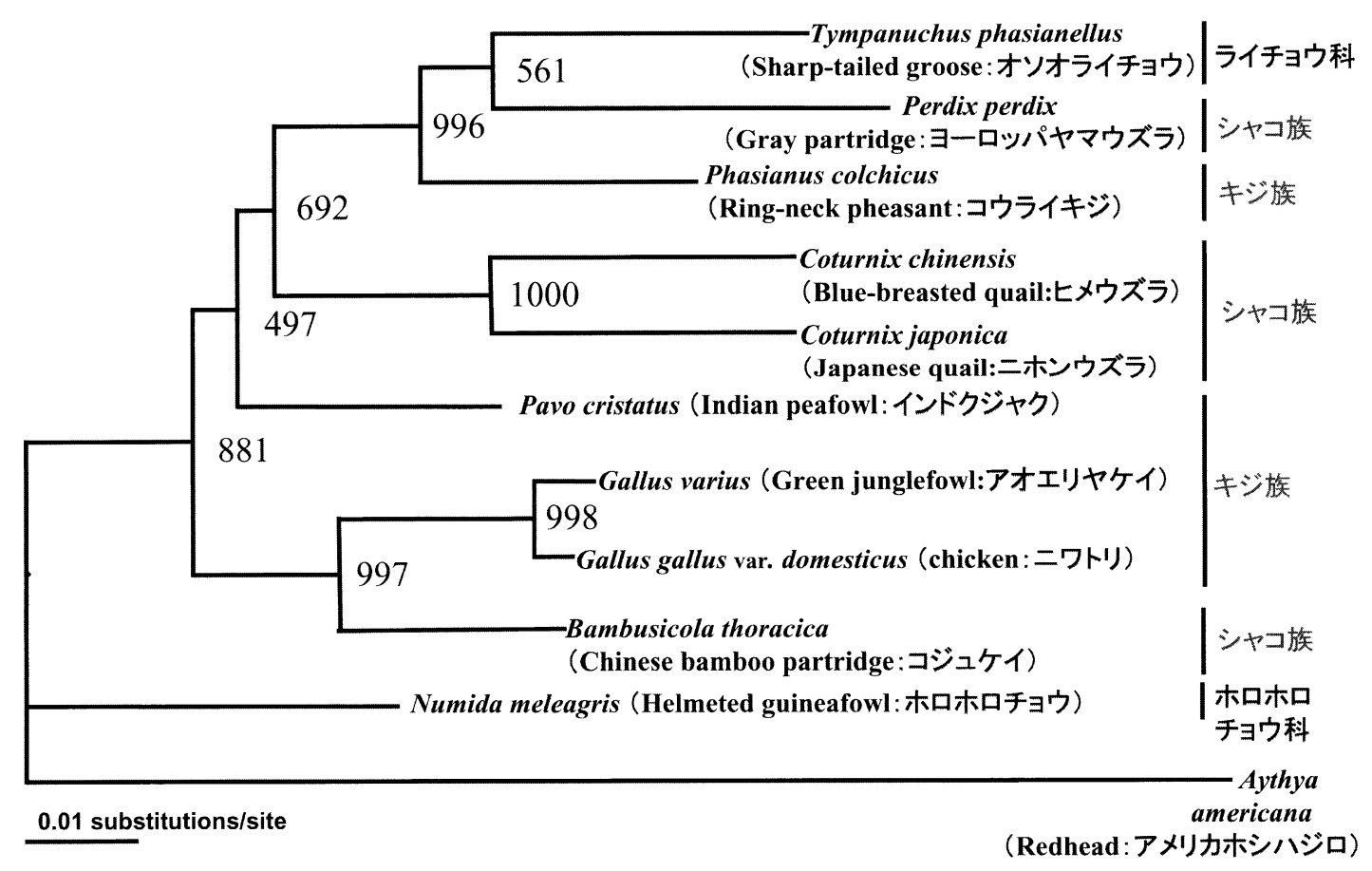

図 1. ミトコンドリアDNA の塩基配列に基づく最尤（Maximum Likelihood：ML) 系統樹。系統解析にはコジュケイ (Chinese bamboo partridge: Bambusicola thoracica)、ヒメウズラ (Blue-breasted quail: Coturnix chinensis)、ニホ ンウズラ (Japanese quail: Coturnix japonica)、ニワトリ(Chicken: Gallus gallus var. domesticus)、アオエリヤケイ (Green junglefowl: Gallus varius)、ホロホロチョウ(Helmeted guineafowl: Numida meleagris)、インドクジャク (Indian peafowl: Pavo cristatus)、コウライキジ(Ring-neck pheasant: Phasianus colchicus)、ホソオライチョウ (Sharp-tailed groose: Tympanuchus phasianellus)、および外群にはアメリカホシハジロ (Redhead: Aythya americana) を用いた。ミトコンドリア 2 遺伝子 (ND2,Cytb) の第 3 コドンの塩基配列に基づき、HKY85-F モデル を用いた ML 系統樹 $(\alpha / \beta=12.264)$ 。図中の各分岐に示した数值は、RELL (Resampling of Estimated LogLikelihood of Sites) 法によりブートストラップ值 $(1,000$ 回試行)を示めす。0.01 は、substitutions/siteを示す。 (Nishibori 5 2004)

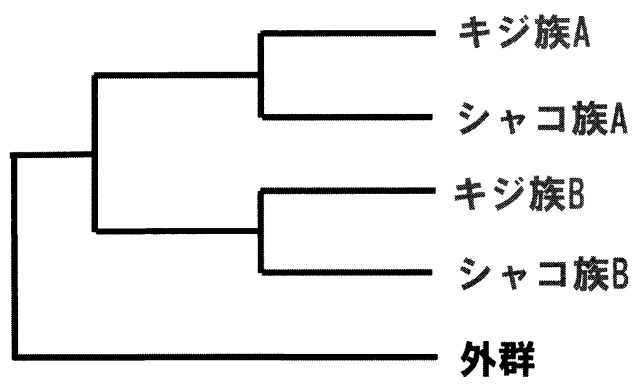

図 2. キジ科の分子系統における「族 (tribe) 」の系統関係

ホンウズラが単系統となった。以上の結果はともにキ ジ族とシャコ族とが同じ単系統の中にそれぞれ含まれ ていることから、分子系統では形態・形質による「族」 の分類とは矛盾する結果であった(図 2)。Kimball ら (1999) は「キジ族とシャコ族はそれぞれが単系統であ る」という説を否定し、著者らの研究結果もこの説を
否定するものであった。したがって、キジ族とシャコ 族とはそれぞれの独立した祖先種を持つのではなく、 共通の祖先種からまず分岐が掞こり、その中のある単 系統内でキジ族扔よびシャコ族に分類されている種が 成立したものと考えられる(図2)。それぞれの単系統 内にキジ族とシャコ族とが出現したことは、形態分類 学上の収斂進化の一例であろうと考えられる。鳥類に おける収斂進化の例として、ツバメ (House (Barn) Swallow: Hirundo rustica) とイワッバメ (House Martin: Delichon urbica) がある。両者はともに飛んでいる昆虫 を飛びながら捕らえて食べるのに適した形態であり、 そのために外見上も非常によく似ている。しかし、分 子系統学的な解析から、ツバメはスズメ（Tree Sparrow: Passer montanus) などの鳴禽類に近く、イワ ツバメはハチドリ (Hummingbird: Amazilia amabilis)に 近縁であるとされている (Sibleyと Ahlquist 1987)。こ のように形態形質による分類は、分子系統と異なるこ 
とがあり、この原因はおもに収斂進化によるものであ る。以上のことから、キジ目における族 (tribe)の分 類は、生物系統学的立場からは正しくはないものと 判断される。キジ目における系統関係 (遺伝的類縁 関係)については、主に従来の形態・形質による分類 学的な情報のみから推定することは難しく、分子系 統学的手法による分析結果を取り入れた系統学によ る新たなキジ目の系統樹が必要である。著者らおよ びKimballらのグループが構築した分子系統樹から、 1 ) キジ族とシャコ族はそれぞれ単系統ではない (Nishibori ら 2001, 2002, 2004)。2) ホソオライチョウ (Sharped-tail grouse: Tympanuchus phasianellus) はライチ ヨウ科に分類されているがキジ科の単系統に含まれる (Nishibori ら 2002, 2004)。3）ホロホロチョウはキジ科 が分化する以前に分岐した (Kimball ら 1999； Nishibori ら 2004)ことが明らかとなった。さらに、4) シチメチ ヨウ(Turkey; Meleagris gallopavo) はキジ科の単系統に 含まれる（Kimball ら 1999；Nishibori ら in preparation）。 5)ツカツクリ科 (family Megapodiidae) およびホウカ ンチョウ科 (family Cracidae) は、キジ目の最も初期に 分岐した（Kimball ら 1999；Dimcheff ら 2000； Nishibori ら in preparation)。6）新大陸に生息するウズ ラ(New world quail; ハウズラ科; family Odontophoridae) はキジ科の分岐以前に分岐していた（Kimball ら 1999； Dimcheff ら 2000; Nishibori ら in preparation)。しかし、 family Odontophoridae (ハウズラ科)の分岐と family Numididae (ホロホロチョウ科) の分岐でどちらが初期 に起こったかは、研究者によってその系統樹はこと なっているために統一した見解はなされていない。
以上のことをまとめて、キジ目の系統樹について図 3 のようなトポロジーであると提案した（西堀と安江 2003)。

\section{5. キジ目における雑種}

キジ目における種間雑種について、ジュケイ属 (Tragopan)、ヤケイ属（Gallus）、コシアカキジ属 (Lophura)、ミミキジ属(Crossoptilon)、ヤマドリ属 (Symaticus)、キジ属(Phasianus)、キンケイ属 (Chrysolophus) およびクジャク属 (Pavo) における属内 で人工授精により誕生した種間雑種の例が報告されて いる。さらにキジ族 (tribe Phasianini) とシャコ族 (tribe Perdicini)、キジ族とジュケイ亜科 (Tetraoninae)、キジ 族とホロホロチョウ亜科 (Numidinae)、キジ族とシチ メンチョウ亜科 (Meleagridinae)、キジ族とホウカンチ ヨウ科(Cracidae)、キジ族とツカツクリ科(Megapodidae) のメンバーとの種間雑種が報告されているが、これら はすべて Gray（1958）の報告であり、キジ族にはニワ トリが用いられ、すべて人為的交雑実験である（この 報告には、詳細な記載はないが、誕生した子供は妊性 のない雑種と考えられる)。一方、ハウズラ亜科 (New world quail: Odontophorinae) との交雑種に関する報告 例はない。これはハウズラ亜科とそのほかのキジ目鳥 類との類縁関係が比較的遠い (Sibley と Ahlquist 1990) ことに起因するものであろうと述べている (Johnsgard 1999)。

一方、自然交雑としては、形態学的な解析から、ミ ヤマハッカン (Kalij: Lophura leucomelane) とハッカン (Silver pheasant: Lophura nycthemera)、およびシロミミ

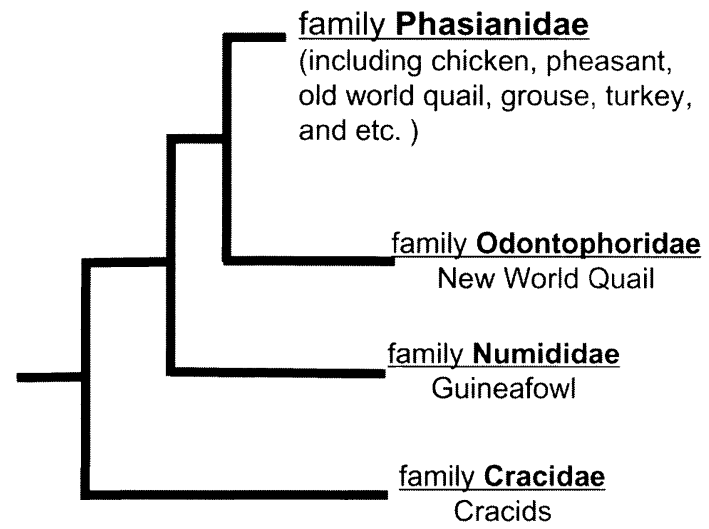

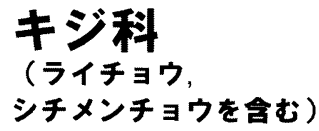

ハウズラ科

ホロホロチョウ科

ホウカンチョウ科

図 3. 著者らの研究成果に基づくキジ目の系統(西堀と安江 2003) 


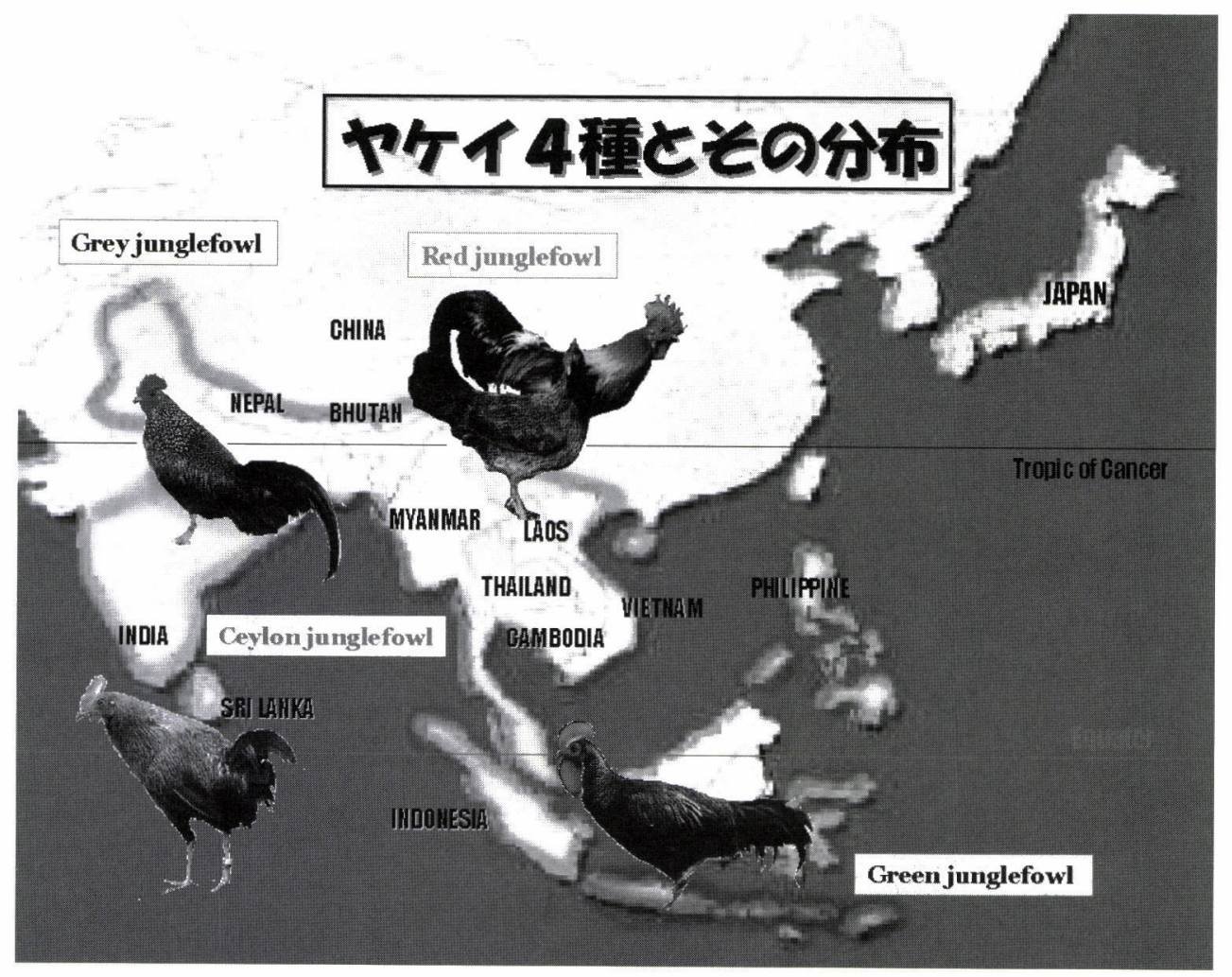

図4. ヤケイ 4 種とその分布

キジ (White ear pheasant: Crossptilon crossptilon) とミミ キジ (Blue ear pheasant: Crossptilon mantchuricum) との 雑種の存在が知られている。これらの種は同所種 (local sympatric species)であり、これらの交雑は偶然 におこっているとされている(Johnsgard 1999)。

\section{6. ヤケイ属における種間雑種の存在}

キジ目ヤケイ属 (order Galliformes, family Phasianidae, genus Gallus) は、セキショクヤケイ (Red Junglefowl: Gallus gallus)、ハイイロヤケイ (Grey Junglefowl: Gallus sonnerati)、セイロンヤケイ (Ceylon Junglefowl: Gallus lafayettei) およびアオエリヤケイ（Green Junglefowl: Gallus varius)の4種からなる (Nishibori ら 2005）（図 4）。ニワトリ（domestic chicken）は、セキシ ヨクヤケイと同種に分類され、Gallus gallus var. domesticus と称されている。

ニワトリの起源に関しては「ニワトリはセキショク ヤケイ (赤色野鷄) のみが家禽化されて成立した」とい う仮説がダーウィンよって初めて提唱された（Darwin 1868）。その根拠とは、1）二ワトリとヤケイとの交雑 種の中で、常に繁殖力を有するのはセキショクヤケイ
との交雑種だけであり、他のヤケイとの交雑種は繁殖 力をもたない場合がある。2）セキショクヤケイの生息 域がヤケイ 4 種の中で最も広い。3) ニワトリ間での交 配を行うと、セキショクヤケイに良く似た個体は誕生 するが、他の3 種のヤケイに似た個体は出現しなかっ た。4) ニワトリの在来種の中には、セキショクヤケイ とよく似た羽色と体型を持つものがいる、である。そ の後、1949 年にハット (Hutt 1949) が、複数のヤケイ がニワトリの起源となっているとする説を提唱した。 その根拠として、1) ニワトリの品種分化は、きわめて 多種多様である(現在では世界で734の品種が登録さ れている(FAO 2000))。2) セキショクヤケイ以外のヤ ケイでも、ニワトリとの間に人工授精により雑種を作 ることは可能であり、それらの中には繁殖力をもつも のがいる、とされている。

ニワトリの起源を明らかにするために、ヤケイ属の 類縁関係について解析されてきた (Hashiguchi ら 1981； Okada ら 1984; Yamashita ら 1994; Fumihito ら 1996)。 Hashiguchi ら (1981) と Okadaら (1984)は、ヤケイ属 4 種およびニワトリの血液タンパク質の多型性から遺伝 子頻度を算出し、デンドログラムを作成してそれぞれ 
の類縁関係を明らかにした。その結果、セキショクヤ ケイがニワトリと遺伝的に最も近縁であり、ダーウィ ンの仮説を支持する結果となっている。また両者はと もにアオエリヤケイがニワトリとは遺伝的に最も遠い 位置にあると報告している。Yamashita ら（1994）は、 DNA フィンガープリントを遺伝指標として、ニワト リとヤケイとの遺伝的類縁関係を分析した。さらに Fumihito ら (1996) は、ミトコンドリアD-loop の約 400 塩基を用いて分子系統樹を作成して系統解析を行っ た。その結果、両者ともに、セキショクヤケイがニワ トリと遺伝的に最も近縁であり、ダーウィンの仮説を 支持する結果となっている。また、ヤケイの中でアオ エリヤケイがニワトリと最も類縁関係が遠いことを明 らかにした。以上のように、これまで解析されてきた ヤケイ属における類縁関係の解析では、セキショクヤ
ケイとニワトリが最も近縁であり、ダーウィンの仮説 が支持されている。

著者らは、現在、キジ目鳥類の系統を明らかにす るために分子遺伝学的な解析を網羅的に行っている (Nishibori ら in preparation)。その一環としてヤケイ属 に扮ける遺伝的類縁関係の解析を行っている。著者 らは、表 2 に示したヤケイ 4 種、ニワトリおよびニホ ンウズラのミトコンドリアおよび核遺伝子の塩基配 列に基づいて分子系統樹を作成し、類縁関係を解析 した。ミトコンドリア遺伝子に基づく系統樹 (図 5) で は、ハイイロヤケイのうちの2 羽 (GyJFLAO および GyJFTAMA) は、ニワトリ（WL, WR, NHR1, NHR2, NLAO, Silkie) およびセキショクヤケイ（RJFban, RJFgal, RJFspa) と同じ群に位置したが、GyJFINDは二 ワトリ拉よびセキショクヤケイとは離れて位置した。

表 2. 実験に用いたヤケイ、ニワトリのサンプルリスト

\begin{tabular}{|c|c|c|c|c|}
\hline Species and breeds & $\begin{array}{l}\text { Abbreviation of } \\
\text { individual }\end{array}$ & $\begin{array}{l}\text { No. of } \\
\text { birds }\end{array}$ & Sex & Place and year of sampling \\
\hline \multicolumn{5}{|l|}{ ヤケイ } \\
\hline \multicolumn{5}{|l|}{$\begin{array}{l}\text { Red Junglefowl（セキショクヤケイ） } \\
\text { (Gallus gallus) }\end{array}$} \\
\hline Gallus gallus gallus & RJFgal & 1 & 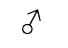 & Manila, Philippine (1998) \\
\hline Gallus gallus spadiceus & RJFspa & 1 & $\sigma$ & Vientiane, Lao P.D.R. (1998) \\
\hline Gallus gallus bankiva & RJFban & 1 & $\delta$ & Bali, Indonesia (1990) \\
\hline $\begin{array}{l}\text { Green Junglefowl（アオエリヤケイ） } \\
\quad \text { (Gallus varius) }\end{array}$ & GJF & 1 & 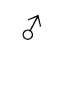 & Bali, Indonesia (1990) \\
\hline \multirow{3}{*}{$\begin{array}{l}\text { Grey Junglefowl（ハイイロヤケイ） } \\
\text { (Gallus sonnerati) }\end{array}$} & GyJFLAO & 1 & đ & Lao Zoological Park, Vientiane, Lao P.D.R. (1998) \\
\hline & GyJFTAMA & 1 & 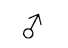 & Tama Zoological Park, Tokyo, Japan (1982) \\
\hline & GyJFIND & 1 & 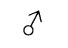 & Delhi National Park, Delhi, India (1995) \\
\hline $\begin{array}{l}\text { Ceylon Junglefowl （セイロンヤケイ） } \\
\quad \text { (Gallus lafayettei })\end{array}$ & CJF & 1 & 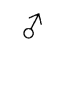 & Tama Zoological Park, Tokyo, Japan (1999) \\
\hline \multicolumn{5}{|l|}{ ニワトリ } \\
\hline $\begin{array}{l}\text { Laos native chicken } \\
\text { (Gallus gallus var. domesticus) }\end{array}$ & NLAO & 1 & 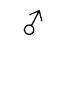 & Vientiane province, Lao P.D.R. (1998) \\
\hline \multicolumn{5}{|l|}{ ニホンウズラ } \\
\hline Japanese quail (Coturnix japonica) & JQ & 1 & 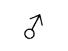 & Hiroshima University, Hiroshima, Japan (2000) \\
\hline \multicolumn{5}{|c|}{ 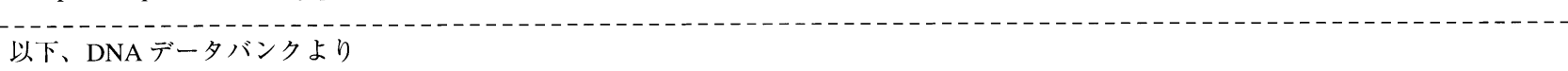 } \\
\hline \multicolumn{5}{|c|}{ ニワトリ } \\
\hline \multicolumn{5}{|l|}{ Domesticated chicken (Gallus gallus var. domesticus) } \\
\hline White Leghorn (DDBJ/GenBank/EMBL: AP003317) & WL & 1 & ð & \\
\hline White Plymouth Rock (DDBJ/GenBank/EMBL: AP003318) & WR & 1 & $\delta$ & \\
\hline New Hampsher Red (DDBJ/GenBank/EMBL: AY235570) & NHR 1 & 1 & ND & \\
\hline New Hampsher Red (DDBJ/GenBank/EMBL: AY235571) & NHR2 & 1 & ND & \\
\hline Silkie (DDBJ/GenBank/EMBL: AB086102) & Silkie & 1 & $\delta$ & \\
\hline
\end{tabular}
注：詳細は、Nishibori ら (2005) を参照 ND: no data 

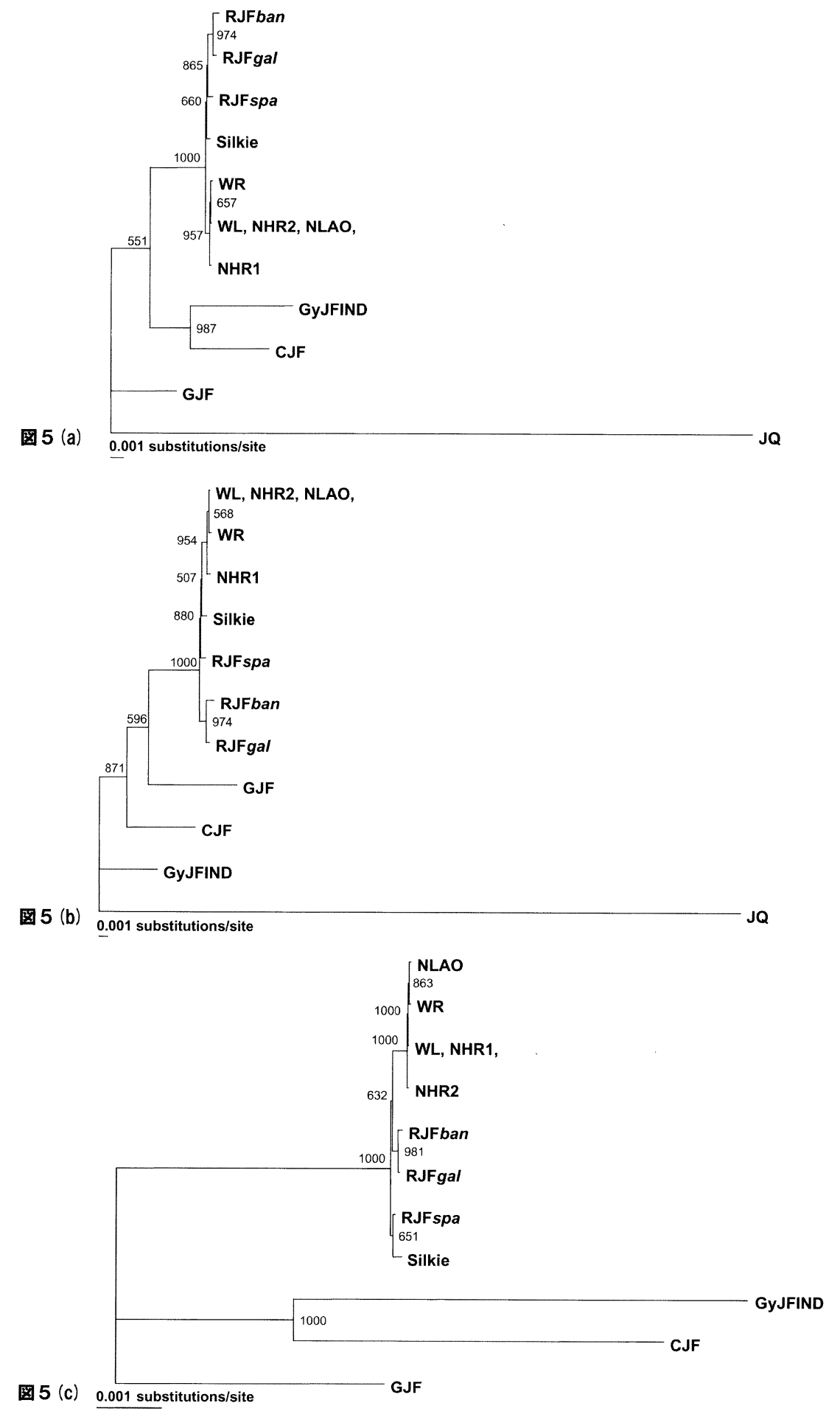

図 5. ミトコンドリアDNA の塩基配列に基づくML系統樹。RJF はセキショクヤケイを示し、RJFgal は gallus 覀種、 RJFspa は spadiceus 要種、RJFban は bankiva 要種。GyJF はハイイロヤケイを示し、GyJFLAO は Laosで入手し た個体、GyJFTAMA は多摩動物園から入手した個体、GyJFINDはインドで捕獲された個体。CJFはセイロンャ ケイ、GJFはアオエリヤケイを示す。WLはホワイトレグホーン、WR はホワイトプリマスロック、NHRはニュ ーハシプシャーレッド、NLAOはラオス在来鷄、Silkie はウコッケイ、JQはニホンウズラを示す。それぞれの詳 練は表 2 を参照いただきたい。(a)ミトコンドリア13 遺伝子 (ND1, ND2, COI, COII, ATPase8, ATPase6, COIII, $N D 3, N D 4 L, N D 4, N D 5, C y t b, N D 6$ ）の第 1、第 2 コドンの塩基配列に基づいた系統樹。（b）ミトコンドリア 12 遺伝 子 (ND6を除く)のアミノ酸配列に基づいた系統樹。(c) ミトコンドリア13 遺伝子 ( $\mathrm{a}$ と同様)の第 3 コドンの塩基 配列に基づいた系統樹。図中の各分岐に示した数值は、ブートストラップ值 $(\mathbf{1 , 0 0 0}$ 回試行) で、500 以上を示し た。(Nishibori ら 2005) 
セイロンヤケイ (CJF) およびアオエリヤケイ (GJF) は、 ニワトリおよびセキショクヤケイとは離れて位置し た。ここでハイイロヤケイは 1 つの種でありながら 2 つの群に位置する結果となった。この疑問を明らかに するために、2つの核遺伝子 $(O T C$ intron 9 および $C R I)$ の塩基配列を決定し、その配列を基に分子系統樹を作 成した。

$O T C$ intron9に基づく系統樹（図 6）では、ニワトリ、
セキショクヤケイおよびハイイロヤケイ (GyJFLAO) の 1 つのアレルがClade A、ハイイロヤケイ (GyJFTAMA, GyJFIND およびGyJFLAO の一方のアレル）およびセ イロンヤケイがClade B、およびアオエリヤケイが Clade C となった。Chicken repeat $1(C R 1)$ に基づく系統 樹 (図 7) では、Clade A にニワトリとセキショクヤケ イ、Clade Bにハイイロヤケイとセイロンヤケイ、 Clade Cにアオエリヤケイが位置した。以上から、ハ

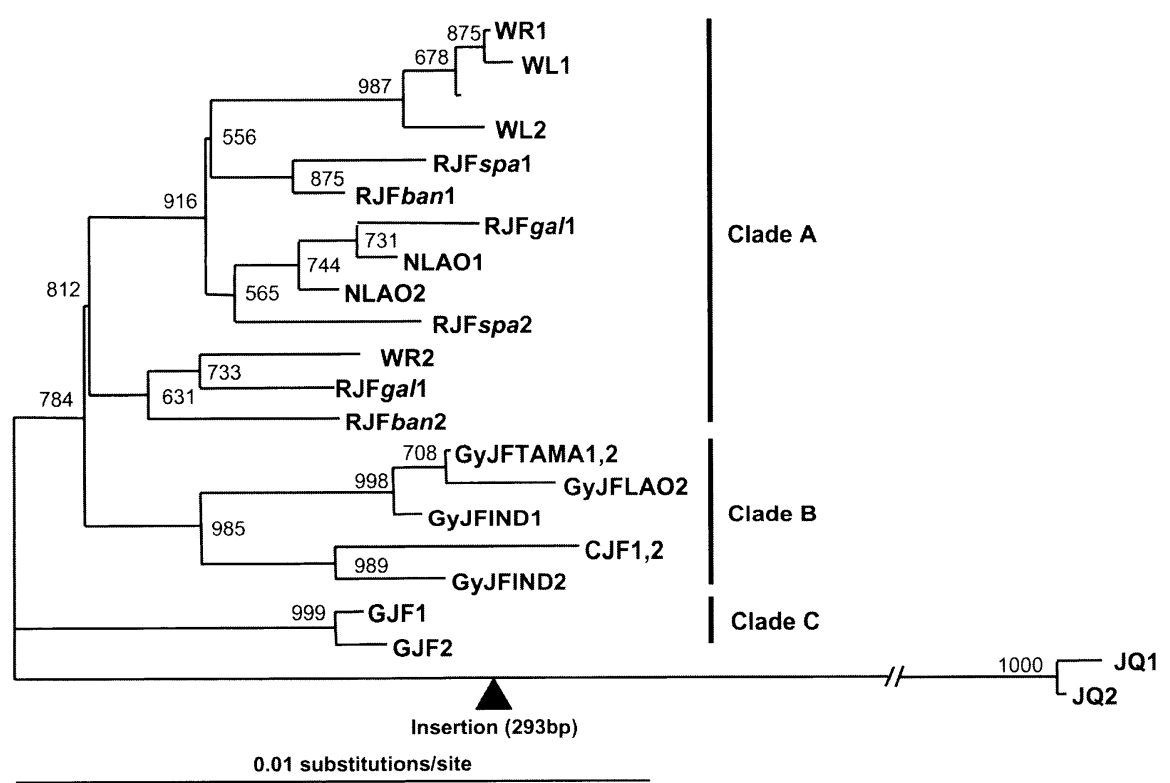

図 6. $O T C$ intron9 の塩基配列に基づく ML 分子系統樹。JQに、PRKDC (293bp) と相同性の高い挿入配列を見つけた。 ヤケイ属は、Clade A 〜 Cの 3つのクレイドとなった。（Nishibori ら 2005）

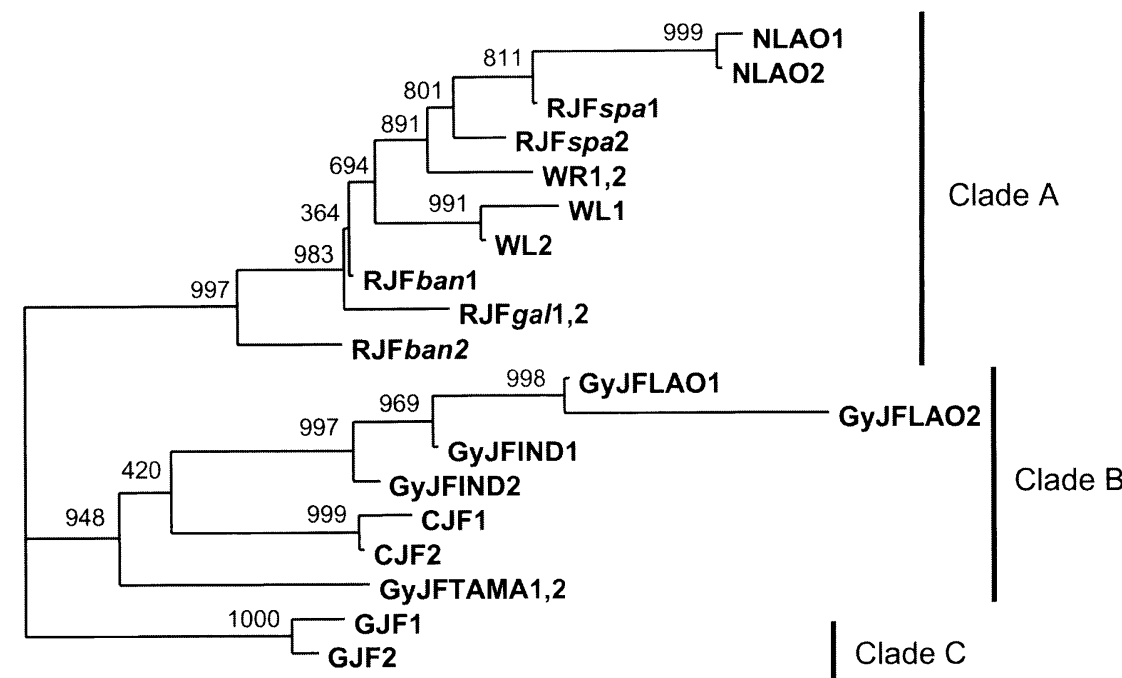

0.001 substitutions/site

図 7. Chicken repeat $1(C R 1)$ の塩基配列に基づく ML 分子系統樹。JQでは CR1 を検出できなかったために系統解析に は用いていない。ヤケイ属は、Clade A～Cの3つのクレイドとなった。（Nishibori ら 2005） 
イイロヤケイのアレルは二者択一的に、ニワトリ・セ キショクヤケイとクラスターをつくり、一方ではセイ ロンヤケイともクラスターを作ることが明らかとなっ た。加えて、ニワトリとセキショクヤケイのアレルが 択一的にクラスターを作っていることが明らかとなっ た。以上のことから、ハイイロヤケイとニワトリ拉よ びセキショクヤケイとの種間雑種の存在が強く示唆さ れた。

これまでの結果と同様にセキショクヤケイが、現在 のニワトリの成立に強く係わっており、さらに著者ら の研究からハイイロヤケイおよびセイロンヤケイの関 与も示唆された。

一方、種間雑種が確認されたセキショクヤケイ、ハ イイロヤケイなどは、それぞれ別種に分類されている (Sibley と Ahlquist 1990)。しかし、種間の交雑が過去 におこり、さらにその次世代へと子孫が継続されてき ていることから、マイヤーの生物学的種の概念 (Mayr 1942）に準じると、これらのヤケイおよびニワトリは 別種ではなく、同種で別亜種に分類される方がふさわ しいものと判断される。

\section{7. イワシャコ属における種間雑種の存在}

イワシャコ属 (order Galliformes, family Phasianidae, genus Alectoris)には7種（ハイイロイワシャコ(Rock partridge: A. graeca)、イワシャコ (Chukar partridge: A. chukar)、オオイワシャコ(Przewalski's rock partridge: A. magna)、ノドグロイワシャコ (Philby's rock partridge: A. philbyi)、チャエリイワシャコ (Barbary partridge: A. barbara)、アカアシイワシャコ(Redlegged partridge: A. rufa)、アラビアイワシャコ (Arabian chukar: A. melanocephala) が分類され、ヨーロッパ、ア ジア拉よびアフリカに広く分布している。アカアシイ ワシャコは、地中海北部扔よび西部、つまりイベリア 半島、南フランス抄よび中央フランス、イタリア北西 部、コルシカ島に生息する在来種である。さらにイギ リスなどヨーロッパ諸国にも導入されている (Randi ら 2003)。アカアシイワシャコは、スペイン、フラン スおよびイタリアではもっとも重要な狩絾鳥の1 種で ある。アカアシイワシャコの狩猟圧が継続して高く、 ヨーロッパ種保存事業リスト (SPEC：the list of the species of European conservation concern) で「低リスク」 種、つまりその生息数が緩やかな減少傾向を示す種と してリストアップされている (BirdLife International 2004）。これをうけて、多くの農家が、アカアシイワ シャコを生産し、放鳥している。具体的には、スペイ
ンで年間 500 万個体以上が放鳥されている。一方、こ れまで生息していなかった地域への放鳥あるいは生産 による雑種の放鳥などにより種間雑種の存在の可能性 に対する䋰念が浮上してきている。スペインの狩猟法 では、外来種㧍よびそれらの雑種の放鳥は禁止されて いる。この問題は、野生集団の遗伝構造に人為的から 重要な影響をもたらすことは明らかである。

南フランスとイタリア国境付近抢よびスペインで は、アカアシイワシャコと八イイロイワシャコの雑種 の存在が報告されている (Randi と Bernard-Laurent 1999; Negro ら 2001)。Randi と Bernard-Laurent (1999) は、南フランスとイタリア国境に生息するアカアシイ ワシャコ、ハイイロイワシャコ抢よびその雨者がとも に生息する地域で捕獲された個体について6つのアロ ザイムのタイプを解析し、その集団に扔ける頻度およ びアレルタイプを明らかにした。この結果、アカアシ イワシャコとハイイロイワシャコが共存する地域で は、アロザイムのタイプが両者の中間的なタイプにな ることを明らかにした。

Negro ら (2001) は、RAPD (Random Amplified Polymorphic DNA) マーカー解析により、スペインにお けるアカアシイワシャコとハイイロイワシャコ、拈よ び両者の交雑種を人為的に作出し、そのタイプを調查 した。その結果、図8に示すように、アカアシイワシ

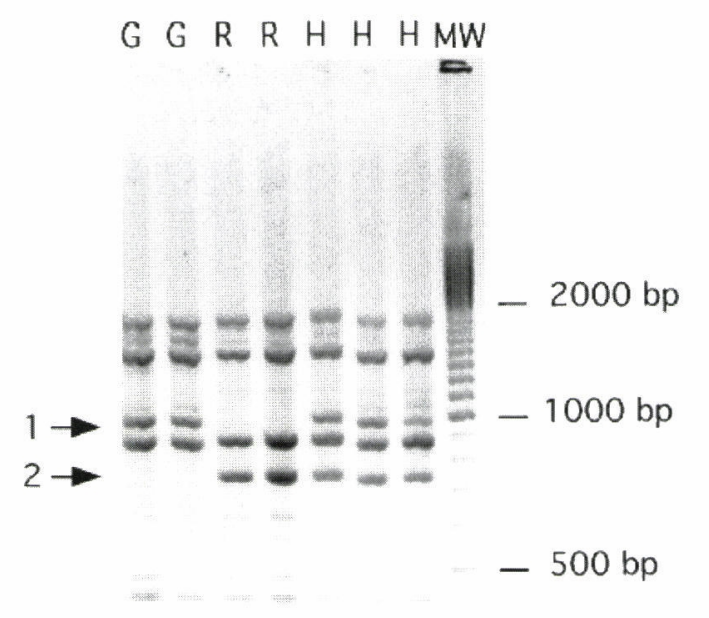

図 8. RAPD 解析プロファイル (OP-08-1000 マーカー)。 サンプルは左から、ハイイロイワシャコ 2 個体 (G)、アカアシイワシャコ 2 個体 (R) および; ハイ イロイワシャコとアカアシイワシャコ雑種 $\mathbf{3}$ 個体 (H)。矢印 1 は、ハイイロイワシャコ特異的断片、 矢印 2 は、アカアシイワシャコ特異的断片を示す。 雑種は矢印 1 と矢印 2 の断片がともに存在する。 MW は分子量マーカーを示す。(Negro ら 2001) 


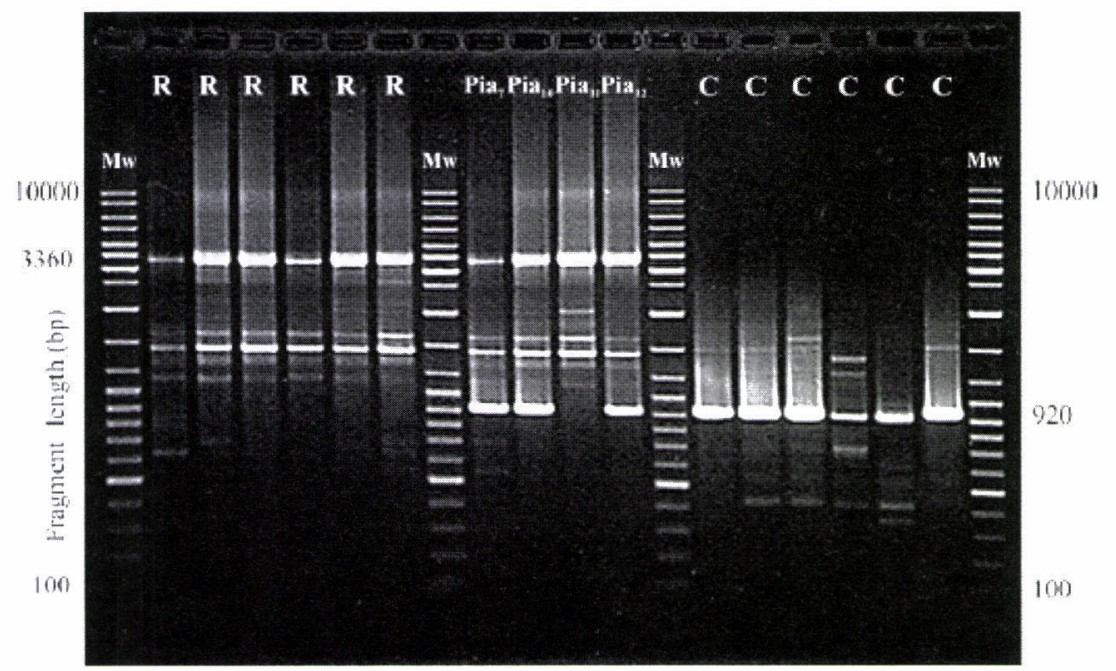

図 9. RAPD 解析プロファイル (OP-C-09マーカー)。Mw は分子量マーカーを示す。サンプルは左から、アカアシイワ シャコ 6 個体 $(\mathbf{R})$; アカアシイワシャコとイワシャコの雑種 4 個体 (Pia；アカアシイワシャコとして捕獲された個 体 : Pianosa, Italy); イワシャコ 6 個体 $(\mathrm{C})$ 。アカアシイワシャコとイワシャコの種特異的增幅断片は、3360 920bpであった。（Barbanera ら 2005）

ヤコのタイプとハイイロイワシャコのタイプの中間的 なタイプになることを報告した。この RAPD 解析技術 を使って狩猟用のアカアシイワシャコを生産する農家 における雑種をモニターするとともに、野生種につい て調査し、両者の雑種の存在を報告した。

イタリアにおいて、Microsatellite markerによる解析 (Baratti ら 2004)、mtDNA D-loopの塩基配列および RAPD 解析 (Barbanera ら 2005) により、アカアシイワ シャコとイワシャコとの雑種の存在が明らかになっ た。イタリアPianosa islandでアカアシイワシャコとし て捕獲された個体のミトコンドリア Cytochrome $b$ およ びD-loopの塩基配列を基に系統樹を作成すると、ア カアシイワシャコとクラスタリングする個体とイワシ ヤコとクラスタリングする個体が存在することが明ら かとなった。これらについてRAPD 解析を行い、図 9 に示したように、アカアシイワシャコとイワシャコの 両者のプロファイルを示した。その結果、ある個体に アカアシイワシャコとイワシャコの遺伝子が存在する 種間雑種の存在が明らかとなった。アカアシイワシャ コとイワシャコは、かつては生息域が異なっていた （異所性；Randi 1996）が、前述のようにアカアシイワ シャコあるいはイワシャコを狩猟目的のために放鳥さ れたことによって、両者の生息域が重なってきた (同 所性) ことが原因で、自然状態での両者の交雑が起こ っているものと考察されている（Barbaneraら 2005）。
以上のように、地中海沿岸諸国でアカアシイワシャ コとイワシャコ、およびハイイロイワシャコにおける 雑種の存在が分子遺伝学的手法を用いて明らかとなっ た。アカアシイワシャコとイワシャコ、アカアシイワ シャコとハイイロイワシャコとの間に種間雑種が自然 環境下で確認されたことから、3者はそれぞれ別種に 分類されているが、マイヤーの生物学的種の概念 (Mayr 1942) に準じると、これらの3種は別種ではな く、同種における別亜種に分類する方がふさわしいも のと判断される。

\section{8. キジ目における種を考える}

自然状態で、形態学的な見地からの雑種が報告され ているミヤマハッカンとハッカン、シロミミキジとミ ミキジについては、今後、分子遺伝学的な解析を行い、 その雑種の存在を確かめる必要がある。また、ヤケイ (ニワトリを含む) 抢よびイワシャコにおいて、分子遺 伝学的に種間雑種の存在が明らかにされている。つま り、これらの種では過去に種間交雑がおこり、さらに その次世代へと子孫が継続されてきていることから、 マイヤーの生物学的種の概念 (Mayr 1942) に準じると、 セキショクヤケイ、ハイイロヤケイおよびニワトリ、 あるいはアカアシイワシャコ、イワシャコおよび八イ イロイワシャコがそれぞれ別種であるということと矛 盾する。したがって、それらは別種ではなく、同種で 
別の亜種に分類される方がふさわしいものと判断する ことができる。しかしながら、自然界で捕獲した個体 の解析はゲノムの中に刻み込まれた歴史のレトロスぺ クティブな解析である。したがって、交雑を実証する ためには、実験室レベルで交雑し、得られた個体につ いて分子遺伝学的解析を行う必要がある。著者らは、 現在これに向けた準備を行っている。

本稿で紹介したような種間雑種を分子遺伝学的に検 出し、その上で純系の子孫のみを残すことは遺伝資源 保存のために重要であると考えられる。種 (亜種)を保 存する場合、自然保護の立場から放鳥する際には遺伝 的に明らかな純系の個体を交雑の可能性のある別種が 生息していない地域に限って放鳥するなどの対策およ びその規則を明確に定めなければならないと思われ る。一方、動物生産 (畜産) の立場では、有用な形質を 担う「遺伝子」源が重要である。上述のように、種 (亜 種)の維持、生息域等の保全を行うことが、動物生産 ではその「遺伝子」源となると著者らは確信している。

\section{引用文献}

Baratti M, Ammannati M, Magnelli C, Dessi-Fulgheri F. 2004. Introgression of chukar genes into a reintroduced red-legged partridge (Alectoris rufa) population in central Italy. Animal Genetics, 36: 29-35.

Barbanera F, Negro JJ, Giuseppe GDi, Bertoncini F, Cappelli F, Dini F. 2005. Analysis of the genetic structure of red-legged partridge (Alectoris rufa, Galliformes) populations by means of mitochondrial DNA and RAPD markers: a study from central Italy. Biological Conservation, 122: 275-287.

BirdLife International Birds in Europe. 2004. Population estimates, trends and conservation status. (Cambridge, UK: BirdLife Conservation series No.12). http://www. birdlife.net/datazone/species/index.html?action=SpcHT MDetails.asp\&sid $=144 \& \mathrm{~m}=0$

Darwin C. 1868. The variation of animals and plants under domestication. John Murray, London.

Dimcheff DE, Drovetski SV, Krishnan M, Mindell DP. 2000. Cospeciation and horizontal transmission of avian sarcoma and Leukosis virus $g a g$ genes in Galliform birds. Journal of Virology, 74: 3984-3995.

Fumihito A, Miyake T, Takeda M, Shingu R, Endo T, Gojobori T, Kondo N, Ohno S. 1996. Monophyletic origin and unique dispersal patterns of domestic fowls. Proceedings of the National Academy of Sciences of the United States of America, 93: 6792-6795.

Gray AP. 1958. Bird hybrids: A check-list with bibliography. Commonwealth Agricultural Bureaux, Farnham Royal, UK.

Hashiguchi T, Tsuneyoshi M, Nishida T, Hgashiuwatoki H, Hiraoka E. 1981. Phylogenetic relationships determined by the blood protein types of fowls. Japanese Journal Zootechnical Science, 52: 713 - 729.

Hutt FB. 1949. Genetics of the fowl. McGraw Hill Book Company Inc., New York.

Johnsgards PA. 1999. The Pheasants of the World: Biology and Natural History, 2nd ed. Smithsonian Institution Press, Washington, D.C.

Kimball RT, Braun EL, Zwartjes PW, Crown TM, Ligon JD. 1999. A molecular phylogeny of the pheasants and partridges suggests that these lineages are not monophyletic. Molecular Phylogenetics and Evolution, 11: $38-54$.

Mayr E. 1942. Systematics and the origin of the species. Columbia University Press, New York.

Negro JJ, Torres MJ, Godot JA. 2001. RAPD analysis for detection and eradication of hybrid partridges (Alectoris rufa $\times$ Alectoris graeca) in Spain. Biological Conservation, 98: 18-24.

Nishibori M, Hayashi T, Tsudzuki M, Yamamoto Y, Yasue H. 2001. Complete sequence of Japanese Quail (Coturnix japonica) mitochondria genome and its genetic relationship with those of related species. Animal Genetics, 32: 380-385.

Nishibori M, Tsudzuki M, Hayashi T, Yamamoto Y, Yasue H. 2002. Complete nucleotide sequence of the Coturnix chinensis (blue-breasted quail) mitochondria genome and a phylogenetic analysis with related species. Journal of Heredity, 93: 439-444.

西堀正英・安江博. 2003. ミトコンドリアDNAによる キジ目家禽の分子系統. 動物遺伝育種研究, 30 : $29-35$.

Nishibori M, Hayashi T, Yasue H. 2004. Complete nucleotide sequence of Numida meleagris (Helmeted Guineafowl) mitochondrial genome. Journal of Poultry Science, 41: 259-268.

Nishibori M, Shimogiri T, Hayashi T, Yasue H. 2005. Molecular evidence for hybridization of species in the genus Gallus except for Gallus varius. Animal Genetics, 36: 367-375. 
Okada I, Yamamoto Y, Hashiguchi T, Ito S. 1984. Phylogenetic studies on the Japanese native breeds of chickens. Japanese Poultry Science, 21: 318-329.

Randi E. 1996. A mitochondrial cytochrome $b$ phylogeny of the Alectoris partridges. Molecular Phylogenetics and Evolution, 6: 214-227.

Randi E, Bernard-Laurent A. 1999. Population genetics of a hybrid zone between the red-legged partridge and rock partridge. Auk, 116: 324-337.

Randi E, Tabarroni C, Rimondi S, Lucchini V, Sfougaris A. 2003. Phylogeography of the rock partridge (Alectoris graeca). Molecular Ecology, 12: 2201 - 2214.

Sibley CG, Ahlquist JE. 1987. Avian phylogeny reconstructed from comparisons of genetic material, DNA. In Molecules and Morphology in Evolution: Conflict or Compromise? (Patterson C, ed.) 95-121. Cambridge University Press, Cambridge.

Sibley CG, Ahlquist JE. 1990. Phylogeny and classification of birds: a study in molecular evolution. New Heaven \& London: Yale University Press.

Sibley CG, Monroe BL Jr. 1990. Distribution and taxonomy of birds of the world (Sibley CG, Monroe BL Jr, eds.), London: Yale University Press.

Yamashita H, Okamoto S, Maeda Y, Hashiguchi T. 1994. Genetic relationships among domestic and Jungle Fowls revealed by DNA fingerprint analysis. Japanese Poultry Science, 31: 335-344. 